\title{
Penerapan Jaringan Syaraf Tiruan dalam Memprediksi Tingkat Kriminal di Kabupaten Simalungun Menggunakan Algoritma Backpropagation
}

\author{
Muhammad Julham ${ }^{1}$, S Sumarno ${ }^{2}$, Fitri Anggraini ${ }^{3}$, Anjar Wanto ${ }^{4}$, S Solikhun ${ }^{5}$ \\ ${ }^{1,2,3,4}$ STIKOM Tunas Bangsa, Pematangsiantar - Indonesia \\ ${ }^{5}$ AMIK Tunas Bangsa, Pematangsiantar-Indonesia \\ Jln. Sudirman Blok A No. 1-3 Pematangsiantar, Sumatera Utara \\ 'mhdjulham@gmail.com, ${ }^{2}$ sumarno@amiktunasbangsa.ac.id, \\ 3ftranggraini850@gmail.com, ${ }^{3}$ anjarwanto@amiktunasbangsa.ac.id, \\ 5 solikhun@amiktunasbangsa.ac.id
}

\begin{abstract}
The number of criminal rates that occur in the area of Simalungun Regency each year experiences an increase and decrease in crime cases each year. For example in the types of gambling crimes, in 2012 there were 89 cases, in 2013 there were 102 cases, in 2014 there were 92 cases, in 2015 there were 102 cases, in 2016 there were 94 cases, and in 2017 there were 86 cases. Then this problem is used as a basis in this study, which aims to provide information in the form of prediction data to the police in an effort to anticipate the rise in cases of types of crime in the following year. Efforts are being made to predict the level of crime in Simalungun Regency by applying the Bacpropagation algorithm ANN method. This research uses MATLAB R2011b and uses 5 architectural models to test the data that will be used for etimation / prediction, namely models 4-20-1, 4-30-1, 4-40-1, 4-50-1, 4- 70-1. Then the best architectural model results obtained are architectural models 4-20-1 with an accuracy of 93\%, with the number of epochs 4575 in 51 seconds and MSE of 0,0009995011. This model will be used to predict Criminal Levels in Simalungun District from 2018 to 2022 with an accuracy of 93\%.
\end{abstract}

Keywords: ANN, Prediction, Criminal Rate, Simalungun District, Backpropagation.

\begin{abstract}
Abstrak
Jumlah tingkat kriminal yang terjadi di daerah Kabupaten Simalungun mengalami penaikan dan penurunan kasus kejahatan di setiap tahunnya. Contohnya pada jenis kejahatan Perjudian, ditahun 2012 ada 89 kasus, ditahun 2013 ada 102 kasus, ditahun 2014 ada 92 kasus, ditahun 2015 ada 102 kasus, ditahun 2016 ada 94 kasus, dan ditahun 2017 ada 86 kasus. Maka permasalahan ini dijadikan dasar dalam penelitian ini, yang bertujuan untuk memberikan informasi berupa data hasil prediksi kepada kepolisian dalam upaya mengantisipasi naiknya kasus pada jenis kejahatan di tahun berikutnya. Upaya yang dilakukan untuk memprediksi tingkat kriminal di Kabupaten Simalungun adalah dengan menerapkan metode JST Algoritma Bacpropagation. Penelitian ini menggunakan Tools MATLAB (versi 7.13 tahun R2011b) dan menggunakan 5 model arsitektur untuk menguji data yang akan digunakan untuk etimasi/prediksi, yaitu model 420-1, 4-30-1, 4-40-1, 4-50-1, 4-70-1. Maka didapatkan hasil model arsitektur terbaik yaitu model arsitektur 4-20-1 dengan akurasi kebenaran sebesar 93\%, dengan jumlah epochs 4575 dalam waktu 51 detik dan MSE sebesar 0,0009995011. Model ini akan digunakan untuk melakukan prediksi Tingkat Kriminal di Kabupaten Simalungun mulai tahun 2018 sampai tahun 2022 dengan akurasi 93\%.
\end{abstract}

Kata Kunci: JST, Prediksi, Tingkat Kriminal, Kabupaten Simalungun, Backpropagation 


\section{Pendahuluan}

Kriminalitas merupakan salah satu perbuatan maupun tindakan sosial yang melanggar aturan, norma hukum yang berhubungan dengan perbuatan merampas (mengambil secara paksa) hak milik orang lain, mengganggu ketertiban di kehidupan bermasyarakat, dan pembunuhan satu maupun sekelompok orang. Latar belakang terjadinya perbuatan kriminalitas biasanya dipicu oleh adanya kepincangan sosial, rasa tidak suka, tekanan dan beban mental, maupun perubahan lingkungan yang terjadi di masyarakat [1]. Tindakan kejahatan atau kriminalitas terjadi karena adanya suatu factor pendukung. Faktor penyebab kejahatan antara lain faktor biologik, sosiologik yang terdiri dari faktor-faktor ekonomi (system ekonomi, populasi, perubahan harga pasar, krisis moneter, kurangnya lapangan kerja dan pengangguran), faktor-faktor mental (agama, bacaan, harian-harian, film), faktor- factor fisik: keadaan Iklim dan lain-lain, dan faktorfaktor pribadi (umur, ras dan nasionalitas, alkohol, perang) [2]. Menurut keterangan lain, Kriminal merupakan segala macam bentuk tindakan dan perbuatan yang merugikan secara ekonomis dan psikologis yang melanggar hukum yang berlaku dalam Negara Indonesia serta normanorma social dan agama. Tindak kejahatan yang dianggap kriminalitas yaitu perampokan, pemerkosaan, bahkan hingga pembunuhan. Banyaknya tindak kejahatan saat ini yang menjadi perhatian dan pemberitaan di berbagai media massa maupun elektronik. Aksi kejahatan yang sering terjadi ialah pembunuhan, baik pembunuhan terencana maupun tidak. Aksi ini bnyak menimbulkan ke khawatiran terhadap masyarakat [3].

Tingkat kriminal yang terjadi di daerah Kabupaten Simalungun pada tiap tahunnya selalu mengalami penaikan dan penurunan kasus kejahatan 102 kasus, ditahun 2014 ada 92 kasus, ditahun 2015 ada 102 kasus, ditahun 2016 ada 94 kasus, dan ditahun 2017 ada 86 kasus. Oleh sebab itu, Pihak pemerintah khususnya kepolisian harus mengetahui jumlah kejahatan atau tindak kriminal yang akan terjadi di tahun yang akan datang, untuk upaya mengantisipasi dan memperkecil tingkat kejahatan yang terjadi di Kabupaten Simalungun. Penulis berharap, penelitian ini nantinya dapat membantu kinerja kepolisian dalam melihat tingkat tindak kriminal di kabupaten Simalungun di tahun yang akan datang, dengan menggunakan algoritma Jaringan Syaraf Tiruan Algoritma Backpropagation, serta memperhatikan dan mencermati adanya tren kejahatan yang fluktuasinya naik-turun. Hal itu sangat diperlukan untuk mengetahui bentuk-bentuk kejahatan apa yang perlu mendapat perhatian dan keseriusan, paling tidak untuk memperkecil tindak kriminal yang meningkat Kabupaten Simalungun tersebut.

Banyak penelitian-penelitian terdahulu yang berkaitan dengan jaringan saraf tiruan yang digunakan untuk melakukan prediksi [4]-[16], maupun yang terkait tentang kriminalitas. Salah satunya penelitian yang berjudul tentang "Upaya Menekan Angka Kriminalitas Dalam Meretas Kejahatan Yang Terjadi Pada Masyarakat". Metode dalam penelitian ini adalah Empiris, yang terdiri dari data primer dan data sekunder. Hasil penelitian ini menggambarkan bahwa trend statistik kriminal yang terjadi di daerah tertentu cenderung menurun karena dipengaruhi oleh pertambahan penduduk, sedangkan jumlah pelaku tindak pidana fluktuatif naik-turun. Upaya-upaya yang dapat dilakukan adalah kebijakan mulai dari tingkat penyidikan sampai pada pembinaan narapidana [17]. Berdasarkan latar belakang inilah penulis melakukan penelitian ini.

\section{Metodologi Penelitian}

\subsection{Data Penelitian}

Data yang digunakan pada penelitian ini adalah data tingkat Kejahatan di Kabupaten Simalungun tahun 2012 hingga 2017 yang diperoleh dari Sistem Informasi laporan kriminal Reskrim Polres Simalungun. 
Tabel 1. Tingkat Kejahatan di Kabupaten Simalungun

\begin{tabular}{clcccccc}
\hline No. & Jenis Kejahatan & \multicolumn{7}{c}{ Tahun } \\
\cline { 3 - 7 } & & $\mathbf{2 0 1 2}$ & $\mathbf{2 0 1 3}$ & $\mathbf{2 0 1 4}$ & $\mathbf{2 0 1 5}$ & $\mathbf{2 0 1 6}$ & $\mathbf{2 0 1 7}$ \\
\hline 1 & UU. Perlindungan Anak & 43 & 48 & 38 & 39 & 36 & 36 \\
2 & KDRT & 26 & 18 & 16 & 15 & 18 & 19 \\
3 & Penyerobotan Tanah & 21 & 18 & 21 & 12 & 11 & 15 \\
4 & Pembunuhan & 3 & 5 & 3 & 4 & 3 & 5 \\
5 & Perjudian & 89 & 102 & 92 & 102 & 94 & 86 \\
6 & Penipuan & 28 & 30 & 24 & 18 & 22 & 12 \\
7 & Pengelapan & 31 & 22 & 28 & 21 & 24 & 20 \\
8 & Curat & 37 & 26 & 24 & 20 & 31 & 21 \\
9 & Curas & 5 & 3 & 4 & 5 & 4 & 6 \\
10 & Curanmor & 12 & 21 & 12 & 16 & 18 & 22 \\
11 & Anirat & 21 & 19 & 20 & 24 & 19 & 28 \\
12 & Korupsi & 1 & 0 & 2 & 0 & 1 & 2 \\
13 & Penadahan & 4 & 6 & 3 & 8 & 5 & 7 \\
14 & Lain - Lain Kejahatan & 24 & 3 & 14 & 16 & 12 & 3 \\
\hline & & \multicolumn{7}{c}{ Sumber : Reskrim Polres Simalungun 2018 }
\end{tabular}

\subsection{Diagram Alir Penelitian}

Gambar berikut merupakan diagram alir yang digunakan pada penelitian ini.

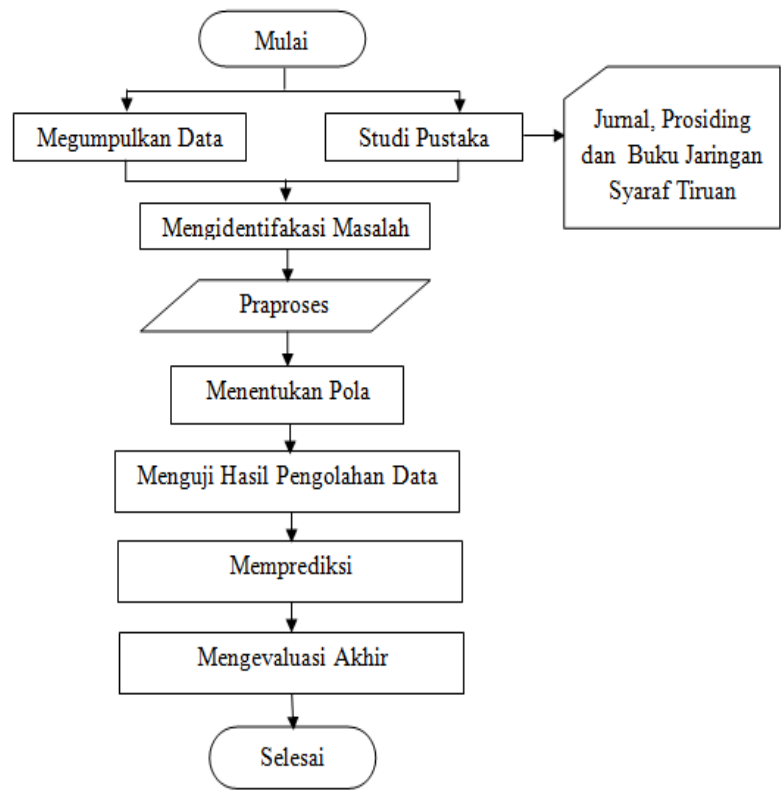

Gambar 1. Diagram Alir Penelitian

Berdasarkan diagram alir penelitian yang disajikan pada gambar 1, maka masingmasing langkah dapat diuraikan sebagai berikut :

1. Mengumpulkan Data

Pada tahap ini, data-data diperoleh dari Sistem Informasi laporan kriminal Reskrim Polres Simalungun.

2. Studi Pustaka

Studi pustaka merupakan langkah awal dalam penelitian ini, studi pustaka ini dilakukan untuk melengkapi pengetahuan dasar dan teori-teori yang digunakan dalam penelitian ini.

3. Mengidentifikasi Masalah

Pada tahap identifikasi masalah ini, dilakukan setelah semua data-data terpenuhi kemudian didapatkan dataset yang sesuai untuk dilakukan proses pada tahap konversi data yang didapat sesuai dengan bobot yang ditentukan. 
4. Praproses

Tahapan yang dikerjakan adalah dengan melakukan perubahan terhadap beberapa tipe data pada atribut dataset dengan tujuan untuk mempermudah pemahaman terhadap isi record, juga melakukan seleksi dengan memperhatikan konsistensi data, missing value dan redundant pada data.

5. Menentukan Model

Hasil dari tahap ini adalah beberapa model jaringan saraf tiruan dengan metode Backpropagation untuk menentukan pola.

6. Menguji Hasil Pengolahan Data

Seteleh proses penentuan model selesai, maka dilakukan tahapan uji coba terhadap hasil pengolahan data dengan menggunakan Software Matlab R2011b (7.13).

7. Memprediksi

Prediksi dilakukan untuk membandingkan jumlah dengan model Jaringan Saraf Tiruan dengan metode Backpropagation yang paling akurat.

8. Mengevaluasi Akhir

Mengevaluasi akhir dilakukan untuk mengetahui apakah testing hasilpengolahan data sesuai dengan yang diharapkan.

\subsection{Normalisasi Data}

Sebelum dilakukan proses pelatihan dan pengujian data, terlebih dahulu dilakukan normalisasi untuk mempermudah melakukan pelatihan dan pengujian data nantinya. Formula normalisasi dapat dilihat pada persamaan berikut [18]-[25]:

$$
x^{\prime}=\frac{0.8(x-a)}{b-a}+0.1
$$

Keterangan :

$$
\begin{aligned}
& x^{\prime} \quad=\text { Hasil data yang telah di normalisasi } \\
& x=\text { Nilai Data yang akan di normalisasi } \\
& a \quad=\text { Nilai terendah dari keseluruhan data } \\
& b \quad=\text { Nilai tertinggi dari keseluruhan data }
\end{aligned}
$$

\section{Hasil dan Pembahasan}

\subsection{Hasil Normalisasi Data}

Sebelum perhitungan dilakukan atau dinormalisasi, data akan dibagi menjadi dua (2) yaitu data pelatihan (training) dan data pengujian (testing). Data training di mulai dari tahun 2012 sampai 2015 dengan target tahun 2016. Data testing di mulai dari tahun 2013 sampai tahun 2016 dengan target tahun 2017.

Tabel 2. Hasil Normalisasi Data Pelatihan

\begin{tabular}{clccccc}
\hline No & Jenis Kejahatan & $\mathbf{2 0 1 2}$ & $\mathbf{2 0 1 3}$ & $\mathbf{2 0 1 4}$ & $\mathbf{2 0 1 5}$ & Target \\
\hline 1 & UU. Perlindungan Anak & 0,43725 & 0,47647 & 0,39804 & 0,40588 & 0,38235 \\
2 & KDRT & 0,30392 & 0,24118 & 0,22549 & 0,21765 & 0,24118 \\
3 & Penyerobotan Tanah & 0,26471 & 0,24118 & 0,26471 & 0,19412 & 0,18627 \\
4 & Pembunuhan & 0,12353 & 0,13922 & 0,12353 & 0,13137 & 0,12353 \\
5 & Perjudian & 0,79804 & 0,90000 & 0,82157 & 0,90000 & 0,83725 \\
6 & Penipuan & 0,31961 & 0,33529 & 0,28824 & 0,24118 & 0,27255 \\
7 & Pengelapan & 0,34314 & 0,27255 & 0,31961 & 0,26471 & 0,28824 \\
8 & Curat & 0,39020 & 0,30392 & 0,28824 & 0,25686 & 0,34314 \\
9 & Curas & 0,13922 & 0,12353 & 0,13137 & 0,13922 & 0,13137 \\
10 & Curanmor & 0,19412 & 0,26471 & 0,19412 & 0,22549 & 0,24118 \\
11 & Anirat & 0,26471 & 0,24902 & 0,25686 & 0,28824 & 0,24902 \\
12 & Korupsi & 0,10784 & 0,10000 & 0,11569 & 0,10000 & 0,10784 \\
13 & Penadahan & 0,13137 & 0,14706 & 0,12353 & 0,16275 & 0,13922 \\
14 & Lain - Lain Kejahatan & 0,28824 & 0,12353 & 0,20980 & 0,22549 & 0,19412 \\
\hline
\end{tabular}


Untuk hasil normalisasi data pengujian dapat dilihat pada tabel berikut ini.

Tabel 2. Hasil Normalisasi Data Pengujian

\begin{tabular}{clccccc}
\hline No & Jenis Kejahatan & $\mathbf{2 0 1 3}$ & $\mathbf{2 0 1 4}$ & $\mathbf{2 0 1 5}$ & $\mathbf{2 0 1 6}$ & Target \\
\hline 1 & UU. Perlindungan Anak & 0,47647 & 0,39804 & 0,40588 & 0,38235 & 0,38235 \\
2 & Kdri & 0,24118 & 0,22549 & 0,21765 & 0,24118 & 0,24902 \\
3 & Penterobotan Tanah & 0,24118 & 0,26471 & 0,19412 & 0,18627 & 0,21765 \\
4 & Pembunuhan & 0,13922 & 0,12353 & 0,13137 & 0,12353 & 0,13922 \\
5 & Perjudian & 0,90000 & 0,82157 & 0,90000 & 0,83725 & 0,77451 \\
6 & Penipuan & 0,33529 & 0,28824 & 0,24118 & 0,27255 & 0,19412 \\
7 & Pengelapan & 0,27255 & 0,31961 & 0,26471 & 0,28824 & 0,25686 \\
8 & Curat & 0,30392 & 0,28824 & 0,25686 & 0,34314 & 0,26471 \\
9 & Curas & 0,12353 & 0,13137 & 0,13922 & 0,13137 & 0,14706 \\
10 & Curanmor & 0,26471 & 0,19412 & 0,22549 & 0,24118 & 0,27255 \\
11 & Anirat & 0,24902 & 0,25686 & 0,28824 & 0,24902 & 0,31961 \\
12 & Korupsi & 0,10000 & 0,11569 & 0,10000 & 0,10784 & 0,11569 \\
13 & Penadahan & 0,14706 & 0,12353 & 0,16275 & 0,13922 & 0,15490 \\
14 & Lain-Lain Kejahatan & 0,12353 & 0,20980 & 0,22549 & 0,19412 & 0,12353 \\
\hline
\end{tabular}

\subsection{Pelatihan and Pengujian}

Penelitian ini menggunakan 5 (lima) model arsitektur jaringan yang digunakan untuk pelatihan (training) dan pengujian (testing) data yakni 4-20-1, 4-30-1, 4-40-1, 4-50-1 dan 4-70-1. Dari ke 5 model arsitektur yang digunakan, yang merupakan model terbaik adalah model 4-20-1 (layer masukan sebanyak 4, layer tersembunyi sebanyak 20 neuron dan 1 layer keluaran).

Adapun kode program pelatihan dan pengujian yang digunakan pada software Matlab sebagai berikut:

> net=newff(minmax $(P),[20,1],\{$ 'logsig','purelin'\},'traingd');

Perintah ini untuk membentuk jaringan Backpropagation dengan 20 neuron hidden dan 1 output . Fungsi aktivasi yang digunakan adalah tansig (sigmoid bipolar) dan purelin (linier) serta Fungsi pelatihan traingd.

> net.IW $\{1,1\}$;

Net.IW $\{1,1\}$ bobot pertama yang digunakan untuk bobot hidden.

> net.b $\{1\}$;

Net.b $\{1\}$ bias yang digunakan untuk bias hidden.

> net. $L W\{2,1\}$;

Net.LW $\{2,1\}$ bobot kedua yang digunakan untuk bobot keluaran.

> net.b $\{2\}$;

Bias yang digunakan untuk bias keluaran.

> net.trainParam.epochs $=100000$;

Perintah untuk menentukan jumlah iterasi (epochs) maksimum pelatihan.

$>$ net.trainParam.goal $=0.001$;

Perintah untuk menentukan batas MSE agar iterasi dihentikan.

> net.trainParam. $L r=0.01$;

Perintah yang digunakan untuk menentukan laju pembelajaran (Learning Rate).

> net.trainParam. show $=1000$;

Perintah yang digunakan untuk menampilkan frekuensi perubahan MSE.

> net=train $($ net $, P, T)$

Perintah ini akan memunculkan jaringan hasil pelatihan.

> $[a, P f, A f, e, P e r f]=\operatorname{sim}($ net $, P,[],[], T)$

Perintah ini digunakan untuk melihat hasil yang dikeluarkan oleh jaringan.

Proses Pelatihan data model arsitektur 4-20-1 dengan aplikasi Matlab dapat dilihat pada gambar berikut. 


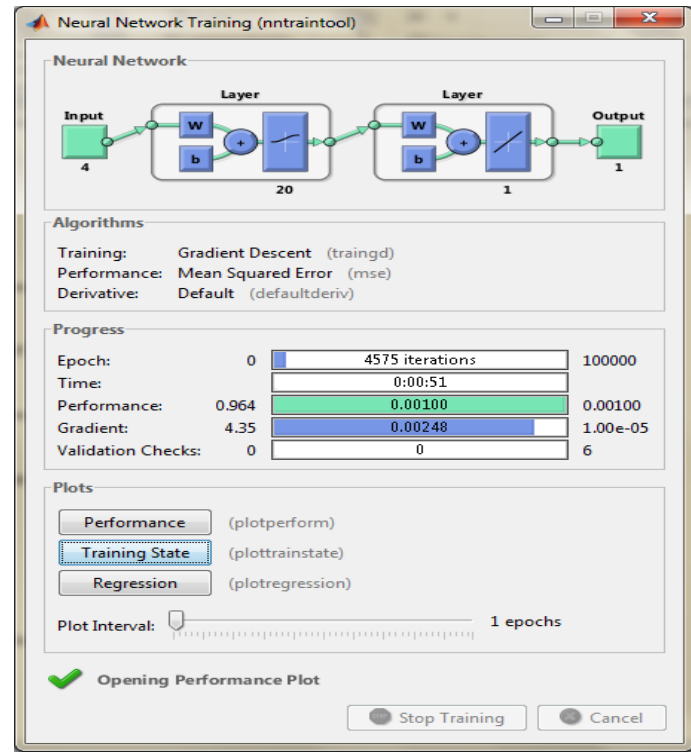

Gambar 2. Pelatihan Menggunakan Model Arsitektur 4-20-1

Pada gambar 2 dapat dijelaskan bahwa pelatihan dengan model arsitektur 4-20-1 menghasilkan epoch sebesar 4575 dalam waktu 51 detik.

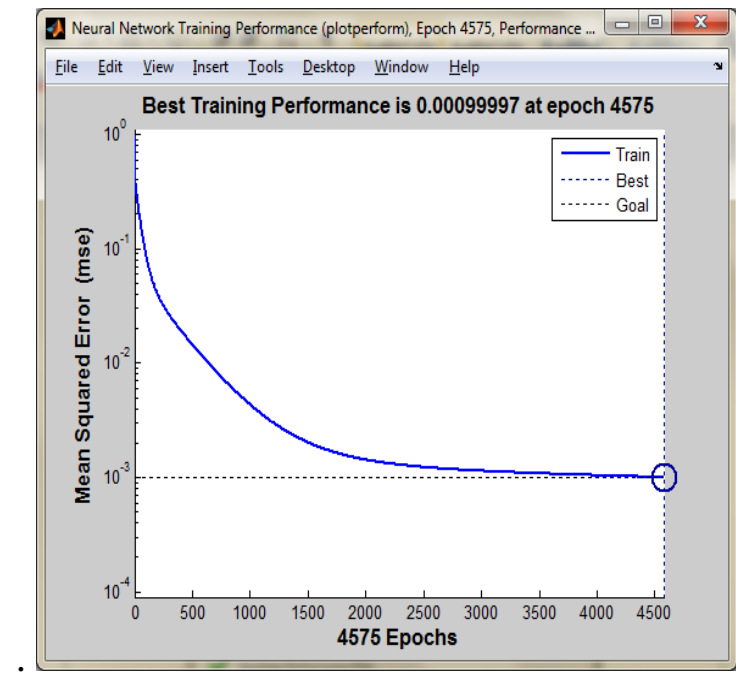

Gambar 3. Kinerja Pelatihan Menggunakan Model Arsitektur 4-20-1

Pada gambar 3 menunjukkan bahwa kinerja pelatihan terbaik dengan model arsitektur 420-1 sebesar 0,00099997 yang dicapai pada epoch 4575. Untuk hasil tabel pelatihan dan pengujian dengan menggunakan model arsitektur 4-2-1 dapat dilihat pada tabel berikut ini.

Tabel 3. Hasil Data Pelatihan dengan Model Arsitektur 4-20-1

\begin{tabular}{cccccc}
\hline No & Pola & Target & Output & Error & SSE \\
\hline 1 & Pola 1 & 0,38235 & 0,36020 & 0,02215 & 0,0004907528 \\
2 & Pola 2 & 0,24118 & 0,26010 & $-0,01892$ & 0,0003581000 \\
3 & Pola 3 & 0,18627 & 0,26070 & $-0,07443$ & 0,0055391536 \\
4 & Pola 4 & 0,12353 & 0,12720 & $-0,00367$ & 0,0000134732 \\
5 & Pola 5 & 0,83725 & 0,85690 & $-0,01965$ & 0,0003859299 \\
6 & Pola 6 & 0,27255 & 0,25850 & 0,01405 & 0,0001973750 \\
7 & Pola 7 & 0,28824 & 0,29850 & $-0,01026$ & 0,0001053642 \\
8 & Pola 8 & 0,34314 & 0,31770 & 0,30120 & 0,0907214400
\end{tabular}




\begin{tabular}{|c|c|c|c|c|c|}
\hline No & Pola & Target & Output & Error & SSE \\
\hline 9 & Pola 9 & 0,13137 & 0,12750 & 0,15070 & 0,0227104900 \\
\hline 10 & Pola 10 & 0,24118 & 0,22530 & 0,17970 & 0,0322920900 \\
\hline 11 & Pola 11 & 0,24902 & 0,22 & 0,02 & 0,0004630935 \\
\hline 12 & Pola 12 & 0,10784 & 0,097 & 0,12760 & 0,0162817600 \\
\hline 13 & Pola 13 & 0,13922 & 0,158 & 0,12950 & 0,0167702500 \\
\hline \multirow[t]{3}{*}{14} & Pola 14 & 0,19412 & 0,21910 & 0,20080 & 0,0403206400 \\
\hline & & & & Jumlah SSE & 0,2266499121 \\
\hline & & & & MSE & 0,0161892794 \\
\hline
\end{tabular}

Tabel 4. Hasil Data Pengujian dengan Model Arsitektur 4-20-1

\begin{tabular}{ccccccc}
\hline No & Pola & Target & Output & Error & SSE & Hasil \\
\hline 1 & Pola 1 & 0,38235 & 0,36270 & 0,01965 & 0,0003862381 & 1 \\
2 & Pola 2 & 0,24902 & 0,24010 & 0,00892 & 0,0000795594 & 1 \\
3 & Pola 3 & 0,21765 & 0,21050 & 0,00715 & 0,0000510804 & 1 \\
4 & Pola 4 & 0,13922 & 0,16210 & $-0,02288$ & 0,0005236918 & 1 \\
5 & Pola 5 & 0,77451 & 0,77750 & $-0,00299$ & 0,0000089413 & 1 \\
6 & Pola 6 & 0,19412 & 0,27570 & $-0,08158$ & 0,0066556803 & 1 \\
7 & Pola 7 & 0,25686 & 0,24370 & 0,01316 & 0,0001732579 & 1 \\
8 & Pola 8 & 0,26471 & 0,28230 & $-0,01759$ & 0,0003095530 & 1 \\
9 & Pola 9 & 0,14706 & 0,14090 & 0,00616 & 0,0000379311 & 1 \\
10 & Pola 10 & 0,27255 & 0,25350 & 0,01905 & 0,0003628651 & 1 \\
11 & Pola 11 & 0,31961 & 0,25060 & 0,06901 & 0,0047620824 & 0 \\
12 & Pola 12 & 0,11569 & 0,10840 & 0,00729 & 0,0000530898 & 1 \\
13 & Pola 13 & 0,15490 & 0,17910 & $-0,02420$ & 0,0005855451 & 1 \\
14 & Pola 14 & 0,12353 & 0,12540 & $-0,00187$ & 0,0000034991 & 1 \\
\hline & & & & Jumlah SSE & 0,0139930149 & $\mathbf{9 3 \%}$ \\
\cline { 4 - 6 } & & & & MSE & 0,0009995011 & \\
\cline { 4 - 6 } & & & & &
\end{tabular}

Pada tabel 3 dan tabel 4 dapat dijelaskan bahwa 14 pola yangvterdapat pada tabel disesuaikan dengan banyaknya data yang digunakan berdasarkan data penelitian. Nilai target diperoleh dari tabel normalisasi data pengujian tahun 2017, nilai output diperoleh dari hasil pelatihan menggunakan aplikasi MATLAB dengan rumus $[a, P f, A f, e, P e r f]=\operatorname{sim}($ net $, P P,[],[], T T)$, nilai error diperoleh dari: target - output, nilai SSE diperoleh dari: error $^{\wedge} 2$ ( $\wedge$ : pangkat), jumlah SSE adalah total keseluruhan nilai SSE. Nilai MSE diperoleh dari: jumlah SSE/ 14 (banyak pola) dan hasil 1 (benar) atau salah (0) diperoleh dari rumus $=I F($ error $<=0,02 ; 1 ; 0)$. Nilai akurasi $(\%)$ diperoleh dari : jumlah benar/ $14 * 100$.

\subsection{Penentuan Model Arsitektur Terbaik}

Setelah pelatihan dan pengujian data pada model arsitektur 4-20-1, 4-30-1, 4-40-1, 450-1 dan 4-70-1 menggunakan bantuan aplikasi Matlab dan Microsoft Excel, model arsitektur terbaik diperoleh 4-20-1 dengan tingkat akurasi 93\%. atau akurasi tertinggi dibandingkan dengan 4 model lainnya. Sehingga diketahui bahwa margin error sebesar 7\% yang diperoleh dari jumlah akurasi maksimum (100\%) dikurangi dengan akurasi yang dihasilkan. Hasil keseluruhan dari 5 model arsitektur pada tabel 5 berikut ini.

Tabel 5. Perbandingan Model Arsitektur yang Digunakan

\begin{tabular}{ccccccc}
\hline No & Arsitektur & \multicolumn{3}{c}{ Training } & \multicolumn{2}{c}{ Testing } \\
\cline { 3 - 7 } & & Epoch & Waktu & MSE & MSE & Akurasi \\
\hline 1 & $4-20-1$ & 4575 & 00.51 & 0,0161892794 & 0,0009995011 & $93 \%$ \\
2 & $4-30-1$ & 5440 & $00: 59$ & 0,0030084022 & 0,0009991489 & $79 \%$ \\
3 & $4-40-1$ & 16791 & $03: 04$ & 0,0010003221 & 0,0009996255 & $86 \%$ \\
4 & $4-50-1$ & 4256 & $00: 36$ & 0,0279910552 & 0,0009992241 & $71 \%$ \\
5 & $4-70-1$ & 15708 & $02: 07$ & 0,0160440675 & 0,0009996935 & $64 \%$ \\
\hline
\end{tabular}




\subsection{Hasil Prediksi}

Selanjutnya, hasil prediksi akan dicari dan diperoleh dengan menggunakan model 420-1 menggunakan rumus mengembalikan nilai seperti berikut.

$\boldsymbol{x}_{n}=\frac{(\boldsymbol{x}-0,1) *(b-a)}{0,8}+a$

Keterangan :

\begin{tabular}{|c|c|}
\hline$x^{\mathrm{n}}$ & $=$ Hasil pengembalian nilai \\
\hline & $=$ Target prediksi \\
\hline & $=$ Nilai terendah dari keseluruhan data \\
\hline 8 dan 0.1 & $\begin{array}{l}=\text { Nilai tertinggi dari keseluruhan data } \\
=\text { Ketentuan Normalisasi pengembalian nilai }\end{array}$ \\
\hline
\end{tabular}

Hasil prediksi tingkat kriminalitas di Kabupaten Simalungun untuk tahun 2018 hingga tahun 2022 berdasarkan rumus pada persamaan (2) dapat dilihat pada tabel 6 berikut.

Tabel 6. Hasil Prediksi Tingkat Kriminalitas di Kabupaten Simalungun

\begin{tabular}{clccccc}
\hline No & \multirow{2}{*}{ Jenis Kejahatan } & \multicolumn{5}{c}{ Tahun } \\
\cline { 3 - 7 } & & $\mathbf{2 0 1 8}$ & $\mathbf{2 0 1 9}$ & $\mathbf{2 0 2 0}$ & $\mathbf{2 0 2 1}$ & $\mathbf{2 0 2 2}$ \\
\hline 1 & UU. Perlindungan Anak & 43 & 48 & 38 & 39 & 36 \\
2 & KDRT & 26 & 18 & 16 & 15 & 18 \\
3 & Penyerobotan Tanah & 21 & 18 & 21 & 12 & 11 \\
4 & Pembunuhan & 3 & 5 & 3 & 4 & 3 \\
5 & Perjudian & 89 & 102 & 92 & 102 & 94 \\
6 & Penipuan & 28 & 30 & 24 & 18 & 22 \\
7 & Pengelapan & 31 & 22 & 28 & 21 & 24 \\
8 & Curat & 37 & 26 & 24 & 20 & 31 \\
9 & Curas & 5 & 3 & 4 & 5 & 4 \\
10 & Curanmor & 12 & 21 & 12 & 16 & 18 \\
11 & Anirat & 21 & 19 & 20 & 24 & 19 \\
12 & Korupsi & 1 & 0 & 2 & 0 & 1 \\
13 & Penadahan & 4 & 6 & 3 & 8 & 5 \\
14 & Lain - Lain Kejahatan & 24 & 3 & 14 & 16 & 12 \\
\hline
\end{tabular}

\section{Kesimpulan}

a. Setelah dilakukan pelatihan dan pengujian menggunakan 5 model arsitektur yakni 4-20-1, 4-30-1, 4-40-1, 4-50-1 dan 4-70-1, maka didapat 1 arsitektur terbaik dengan model 4-20-1 yang memiliki tingkat akurasi tertinggi yaitu 93\% dengan epoch sebesar 4575 iterasi dengan waktu 51 detik dan nilai Mean Squared Error (MSE) sebesar 0,0009995011

b. Model arsitektur 4-20-1 dapat digunakan untuk memprediksi tingkat kriminalitas di Kabupaten Simalungun untuk tahun 2018 hingga tahun 2022.

\section{Daftar Pustaka}

[1] I. F. Astuti, E. Fardinan, and A. Suyatno, "Pemetaan Sosial Sebaran Kriminalitas Di Kota Samarinda Berbasis Single Exponential Smoothing Dan," Jurnal SEBATIK, vol. 19, no. 1, pp. 21-27, 2018.

[2] Y. Yenni and I. Utnasari, "Fuzzy Logic Mamdani Memprediksi Tingkat Kriminalitas," in Seminar SNISTEK, 2019, vol. 2, no. September, pp. 247-252.

[3] S. M. Dewi, A. P. Windarto, I. S. Damanik, and H. Satria, "Analisa Metode KMeans pada Pengelompokan Kriminalitas Menurut Wilayah," Seminar Nasional Sains \& Teknologi Informasi (SENSASI), vol. Juli, pp. 620-625, 2019.

[4] A. Wanto, M. Zarlis, Sawaluddin, and D. Hartama, "Analysis of Artificial Neural Network Backpropagation Using Conjugate Gradient Fletcher Reeves in the 
Predicting Process," Journal of Physics: Conference Series, vol. 930, no. 1, pp. 17, 2017.

[5] E. Siregar, H. Mawengkang, E. B. Nababan, and A. Wanto, "Analysis of Backpropagation Method with Sigmoid Bipolar and Linear Function in Prediction of Population Growth," Journal of Physics: Conference Series, vol. 1255, no. 1, pp. 1-6, 2019.

[6] N. Nasution, A. Zamsuri, L. Lisnawita, and A. Wanto, "Polak-Ribiere updates analysis with binary and linear function in determining coffee exports in Indonesia," IOP Conference Series: Materials Science and Engineering, vol. 420, no. 012089, pp. 1-9, 2018.

[7] Budiharjo, T. Soemartono, A. P. Windarto, and T. Herawan, "Predicting Tuition Fee Payment Problem using Backpropagation Neural Network Model," International Journal of Advanced Science and Technology, vol. 120, pp. 85-96, 2018.

[8] Budiharjo, T. Soemartono, A. P. Windarto, and T. Herawan, "Predicting School Participation in Indonesia using Back-Propagation Algorithm Model," International Journal of Control and Automation, vol. 11, no. 11, pp. 57-68, 2018.

[9] G. W. Bhawika et al., "Implementation of ANN for Predicting the Percentage of Illiteracy in Indonesia by Age Group," Journal of Physics: Conference Series, vol. 1255, no. 1, pp. 1-6, 2019.

[10] A. Wanto et al., "Analysis of the Accuracy Batch Training Method in Viewing Indonesian Fisheries Cultivation Company Development," Journal of Physics: Conference Series, vol. 1255, no. 1, pp. 1-6, 2019.

[11] A. Wanto et al., "Analysis of the Backpropagation Algorithm in Viewing Import Value Development Levels Based on Main Country of Origin," Journal of Physics: Conference Series, vol. 1255, no. 1, pp. 1-6, 2019.

[12] P. Parulian et al., "Analysis of Sequential Order Incremental Methods in Predicting the Number of Victims Affected by Disasters," Journal of Physics: Conference Series, vol. 1255, no. 1, pp. 1-6, 2019.

[13] T. Afriliansyah et al., "Implementation of Bayesian Regulation Algorithm for Estimation of Production Index Level Micro and Small Industry," Journal of Physics: Conference Series, vol. 1255, no. 1, pp. 1-6, 2019.

[14] A. Wanto et al., "Forecasting the Export and Import Volume of Crude Oil , Oil Products and Gas Using ANN," Journal of Physics: Conference Series, vol. 1255, no. 1, pp. 1-6, 2019.

[15] S. Setti, A. Wanto, M. Syafiq, A. Andriano, and B. K. Sihotang, "Analysis of Backpropagation Algorithms in Predicting World Internet Users," Journal of Physics: Conference Series, vol. 1255, no. 1, pp. 1-6, 2019.

[16] B. Febriadi, Z. Zamzami, Y. Yunefri, and A. Wanto, "Bipolar function in backpropagation algorithm in predicting Indonesia's coal exports by major destination countries," IOP Conference Series: Materials Science and Engineering, vol. 420, no. 012087, pp. 1-9, 2018.

[17] A. Rohman, "Upaya Menekan Angka Kriminalitas Dalam Meretas Kejahatan Yang Terjadi Pada Masyarakat," Perspektif, vol. 21, no. 2, pp. 125-134, 2016.

[18] A. Wanto et al., "Model of Artificial Neural Networks in Predictions of Corn Productivity in an Effort to Overcome Imports in Indonesia," Journal of Physics: Conference Series, vol. 1339, no. 1, pp. 1-6, 2019.

[19] I. S. Purba et al., "Accuracy Level of Backpropagation Algorithm to Predict Livestock Population of Simalungun Regency in Indonesia Accuracy Level of Backpropagation Algorithm to Predict Livestock Population of Simalungun Regency in Indonesia," Journal of Physics: Conference Series, vol. 1255, no. 1, pp. 1-6, 2019.

[20] M. R. Lubis, W. Saputra, A. Wanto, S. R. Andani, and P. Poningsih, "Analysis of 
Artificial Neural Networks Method Backpropagation to Improve the Understanding Student in Algorithm and Programming," Journal of Physics: Conference Series, vol. 1255, no. 1, pp. 1-6, 2019.

[21] W. Saputra, J. T. Hardinata, and A. Wanto, "Implementation of Resilient Methods to Predict Open Unemployment in Indonesia According to Higher Education Completed," JITE (Journal of Informatics and Telecommunication Engineering), vol. 3, no. 1, pp. 163-174, 2019.

[22] W. Saputra et al., "Implementation of ANN for Predicting the Percentage of Illiteracy in Indonesia by Age Group," Journal of Physics: Conference Series, vol. 1255, no. 1, pp. 1-6, 2019.

[23] S. Setti and A. Wanto, "Analysis of Backpropagation Algorithm in Predicting the Most Number of Internet Users in the World," JOIN (Jurnal Online Informatika), vol. 3, no. 2, pp. 110-115, 2018.

[24] W. Saputra, J. T. Hardinata, and A. Wanto, "Resilient method in determining the best architectural model for predicting open unemployment in Indonesia," IOP Conference Series: Materials Science and Engineering, vol. 725, no. 1, pp. 1-7, 2020.

[25] S. P. Siregar and A. Wanto, "Analysis of Artificial Neural Network Accuracy Using Backpropagation Algorithm In Predicting Process (Forecasting)," International Journal Of Information System \& Technology, vol. 1, no. 1, pp. 3442, 2017. 